\title{
Article \\ Fire Behavior Prediction in Larch Forests of the Kazakhstan Altai
}

\author{
Aleksandra Volokitina $^{1}\left(\mathbb{D}\right.$, Andrey Kalachev $^{2}$, Mikhail Korets ${ }^{1}$ (D) and Tatiana Sofronova ${ }^{3, *(D)}$ \\ 1 V.N. Sukachev Institute of Forest, Russian Academy of Sciences, Siberian Branch, 660036 Krasnoyarsk, Russia; \\ volokit@ksc.krasn.ru (A.V.); mik@ksc.krasn.ru (M.K.) \\ 2 A.N. Bukeykhan Kazakh Scientific Research Institute of Forestry and Agroforestmelioration, Altai Branch, \\ Shchuchinsk 010000, Kazakhstan; ridder_los@mail.ru \\ 3 Department of English Philology and Department of Physical Geography, V.P. Astafiev Krasnoyarsk State \\ Pedagogical University, 660049 Krasnoyarsk, Russia \\ * Correspondence: tmsofronova@gmail.com; Tel.: +7-(905)-086-3082
}

Citation: Volokitina, A.; Kalachev, A ;

Korets, M.; Sofronova, T. Fire

Behavior Prediction in Larch Forests of the Kazakhstan Altai. Symmetry

2021, 13, 578. https://doi.org/

$10.3390 /$ sym 13040578

Academic Editor: Makovická

Osvaldová Linda

Received: 12 February 2021

Accepted: 29 March 2021

Published: 1 April 2021

Publisher's Note: MDPI stays neutral with regard to jurisdictional claims in published maps and institutional affiliations.

Copyright: (c) 2021 by the authors. Licensee MDPI, Basel, Switzerland. This article is an open access article distributed under the terms and conditions of the Creative Commons Attribution (CC BY) license (https:// creativecommons.org/licenses/by/ $4.0 /)$.

\begin{abstract}
This paper considers automated fire behavior prediction in larch forests of the Kazakhstan Altai based on large-scale vegetation fuel maps (VF maps). First-time pyrological description of the Kazakhstan Altai larch forests was performed, thus facilitating VF maps' creation using forest inventory information in a geographical information system (GIS). Based on the methodological developments of the Sukachev Institute of Forest, types of primary fire carriers were identified for larch forests and other categories of sites. On the example of the Markakol Forestry area (Kazakhstan Altai), our fire growth simulation modeling system was adapted for predicting fire behavior in the mountain terrain. The developed fire simulation software helped not only identify inventory plots ready to burn, but also assess spread rate for fire parts dependent upon weather conditions, predict fire intensity and fire development, and calculate the required manpower and resources for fire suppression. The effects of each specific fire were predicted in terms of percentage of tree mortality dependent upon fire intensity, tree species, and average tree diameter. Examples of VF maps were made for different periods of a fire season and analysis was given to behavior of a simulated surface fire in the Markakol Forestry area.
\end{abstract}

Keywords: fire hazard; fire simulation software; fuel mapping; vegetation fuel classification

\section{Introduction}

Vegetation fires (including forest, steppe, bush, swamp fires) have long been an unsolved global problem for humanity. Great damage is caused by forest fire outbreaks during severe droughts. People have not learned to accurately forecast such extreme weather events yet. There is a need to predict behavior of vegetation fires since it is unrealistic to maintain sufficient resources and manpower in each region to suppress all emerging fires. Increasing technical power will not solve the problem, as evidenced by experience of such developed countries as the USA and Canada, where large efforts have been addressed to develop fire behavior prediction systems along with fire hazard assessment. This experience is not replicable in the Kazakhstan Altai for a number of reasons, first of all, for different historically developed approaches to pyrological classification of vegetation and forest inventory.

Floristic, geobotanical, and limited silvicultural studies prevailed in the Kazakhstan Altai until the beginning of the 20th century. They expanded knowledge about the vegetation and forests of this region but failed to solve specific forest fire-related issues [1]. Until the end of 1991, Kazakhstan was part of the USSR sharing the forest fire protection system and the economic crisis. Only in 2008, with gradual recovery from the economic crisis, a new forest management system began to develop in Kazakhstan along with improvement of forest fire protection. In this case, the main attention was initially paid to 
pine forests [2]. Their fire occurrence was analyzed, and local fire danger scales were developed. Post-fire successions were studied in Siberian fir stands of the southwestern Altai mountains [3]. Research on predicting fire occurrence and fire behavior in larch forests of the Kazakhstan Altai was started only in 2019 within the framework of the Agreement between the Altai Branch of the A.N. Bukeykhan Kazakh Scientific Research Institute of Forestry and Agroforestmelioration and the V.N. Sukachev Institute of Forest Siberian Branch of the Russian Academy of Sciences (SB RAS). The task was set to adapt the Russian fire growth simulation modelling system for fire behavior modelling in larch forests of the Kazakhstan Altai. The system consists of two software: the PGM software for making large-scale vegetation fuel maps and the PGM2 software for fire behavior prediction [4-7].

\section{Study Site}

Mountain forests of the Kazakhstan Altai are characterized by spatial heterogeneity. The Markakol Forestry area, forest inventory data of which was used by us to develop the adapted fire growth simulation software, is located within the mountain-taiga belt in the Markakol depression surrounded by mountainous terrain. Larch forests mixed with dark conifers predominate in this mountain-taiga belt. Siberian larch (Larix sibirica Ledeb.) grows at the altitude from 1400 to $2300 \mathrm{~m}$, mainly on the northern and western slopes, less on the eastern slopes, and is almost absent on the southern slopes where the steppe prevails.

The climate of the Kazakhstan Altai is known for its diversity, but it is poorly studied. Climate diversity is explained by the deep inland position of the territory, as well as complexity of the orographic structure of its landscapes. The Markakol weather station located at the altitude of $1400 \mathrm{~m}$ above sea level provides the following climatic data: Average annual temperature is $4.5^{\circ} \mathrm{C}$, absolute temperature maximum is $29^{\circ} \mathrm{C}$, average annual precipitation is $484 \mathrm{~mm}$, duration of a frost-free period is 68 days, and latest spring frosts are registered on 21 June. The region is prone to spring vegetation fires, which occur when there are sources of ignition available in open areas almost immediately after the snow cover melts. In summer, areas with moss-lichen cover may reach burnable condition for fire to propagate. In case of a dry fall, fall fires are possible.

The relief is typically dominated by wide plateaus, strongly eroded in some places. They are typical for watersheds. Mountain slopes are steep, dissected by deep gorges. The absolute heights of the area range from 900 to $4000 \mathrm{~m}$. The taiga soils of the Kazakhstan Altai belong to the Altai oroclimatic region and are characterized by a seasonal permafrost temperature regime and summer or spring-summer atmospheric moistening.

\section{Literature Review}

Available forest fire spread models were analyzed and a most practical empirical model was chosen before the fire growth simulation modelling system was developed and adapted to the mountain terrain of the Kazakhstan Altai.

There is an extensive review of fire spread models by A.L. Sullivan [8-10]. We distinguished three types of models: analytical, experimental-statistical, and experimentalanalytical $[7,11]$.

An example of an analytical model is the aerothermochemical forest fire model developed by A.M. Grishin $[12,13]$. Combustion processes there are considered at a fundamental level. Combustion of a vegetation fuel layer is analyzed on the basis of the laws of heat and mass transfer and gas dynamics, taking into account a large number of physicochemical vegetation fuel $(\mathrm{VF})$ characteristics and characteristics of environment. The model contains dozens of equations describing three-dimensional processes of mass transfer, phasal and chemical transformations during combustion, and a number of physical and chemical fuel characteristics and characteristics of environment. However, it is difficult to recommend this model for wildfire management, since it is almost impossible to obtain the required initial data for each site covered by vegetation within vast areas. This is not feasible even for one relatively small area, since the model describes combustion of homogeneous 
layers, and under natural conditions, fuel layers differ in composition, density, moisture content, and other characteristics. In addition, such an important characteristic as consumable fuel load changes even during a day under the influence of weather conditions and substrate moisture.

Experimental-statistical models are based on data from experimental fires in specific types of forests. For example, G.N. Korovin's model [14] was developed based on the results of 72 fire experiments. This model involved calculation of spread rate for all tactical fire edges, as well as calculation of fire area and fire perimeter. Canadian model developers included prediction of fire development [15]. The limiting factor for applying models of this type is the limited number of standard complexes with reliable pyrological characteristics. Experimental-statistical models also include purely statistical, rather rough models working with databases on past fires (location and conditions) developed by N. A. Marchenko [16] and Yu. V. Podrezov [17].

Experimental-analytical models are based, as a rule, on synthesis of a large experimental material. For example, Rothermel's model [18] is most widely used in many developed fire simulation modelling systems: Behave Plus, FlamMap, FARSITE, FSPro. Unfortunately, due to differences in approaches to pyrological classification of vegetation, these models cannot be used either in Russia or in Kazakhstan. Therefore, we selected an experimentalanalytical model developed by M.A. Sofronov $[19,20]$ at the V.N. Sukachev Institute of Forest SB RAS, since a method for creating information database has been developed for this model and was tested on one of the forestry areas of the Krasnoyarsk Territory and on four nature reserves. In addition, Kazakhstan forest management uses similar programs to create information databases of forest inventory data in GIS.

M.A. Sofronov's model is based on basic spread rate of a flaming fire edge through different types of primary fire carriers, as well as on relative impact of wind, slope, and relative humidity (including its 24-h fluctuations) on combustion processes. To establish coefficients of relative impact of all these factors, fire experiments were carried out in different forest types having different pyrological characteristics. Based on analysis of several hundred experimental ignitions, which were accompanied by taking samples of fuel beds to determine their moisture content, basic fire spread rate was taken to be the spread rate of a surface fire edge over a specific area under no wind, on a horizontal surface, at the relative air humidity of $40 \%$. Basic fire spread rate, combustion efficiency of a surface fuel layer, and consumed fuel load were determined for each primary fire carrier type, taking into account dynamic weather conditions [21]. The obtained pyrological characteristics were introduced into the developed fire simulation modeling software $[5,6]$ to predict behavior of any surface fire, including not only spread rate of its tactical parts but also its development into ground or crown fire. The developed software was tested through retrospective analysis of surface fire spread both in plain and mountain terrain. The performance test results proved that the developed software is reliable and could be used in forest fire management.

Our developed surface fire growth simulation modelling system included the following key elements: information database (constant information: vegetation fuel maps with pyrological description, fire hazard maps by periods of a fire season, fire spread model; current information: weather data, periods of a fire season) and fire behavior prediction (fire type, fire spread, fire intensity, and fire effects) [22].

\section{Materials and Methods}

\subsection{Pyrological Description}

Pyrological description of larch forests in the Kazakhstan Altai was carried out through analysis of the Forest Type Scheme used in the Kazakhstan forest management. For this purpose, we used the vegetation fuel classification developed at the Sukachev Institute of Forest after long-term field observations for dynamics of drying and moistening of different categories of vegetation plots in different regions of Russia. The research was accompanied by numerous fire experiments conducted using an original technique based 
on J.C. Wright's cylindrical screen [23]. Thus, the main VF group of primary fire carriers obtained characteristics necessary for fire spread prediction [21,24,25].

Pyrological description of larch forests in the Kazakhstan Altai was carried out using methods developed in Russia. All vegetation fuels (VF) in various Russian biogeocenoses are divided into seven groups according to N.P. Kurbatsky's classification [26,27]. Each group has its own distinctive characteristics in terms of their role in initiation and propagation of both flame and smoldering combustion. The VF classification was then developed further and each group was divided into types. For example, we conducted experimental study of moistening and drying patterns for a group of moss-lichen and dead fuel covers under various weather conditions and managed to identify the types of primary fire carriers (PFC types). Also, we divided vegetation fuels belonging to the same group into complexes of the same type-VF types [21].

The most detailed is the classification of primary fire carriers, which are crucial for a vegetation fire to occur and spread over the area. A Brief Identifier of PCF Types has been developed for practical use in the field and for analysis of available schemes of forest types. Based on the classification of VF types, methods for VF mapping have been developed [21]. Initial materials for pyrological description of forest types include a scheme of forest types in the form of a table used in forest inventory with a detailed description of forest types, taxation descriptions of inventory plots, and the developed identifier of PFC types.

When characterizing a forest type according to the PFC type, a subgroup is first determined: If more than $50 \%$ of the area in this type of forest is covered with moss and lichen, this is the moss subgroup. If less than $50 \%$ of moss is absent, it is the litter subgroup.

When determining the PFC type, attention is paid to the following main points: the nature of moss-lichen or dead fuel cover, the nature of soil, and its moisture regime. In the moss subgroup, identification of lichen (e.g., Cladonia spp.) and bog moss (e.g., Sphagnum spp., Polytrichum communis, Polytrichum strictum) PFC types according to the developed identifier is quite simple. Dry moss (e.g., Pleurozium shreberi, Hylokomium splendens, Licranum spp.) and moist moss (e.g., Polytrichum communis, Sphagnum spp.) PFC types differ mainly in the regime of soil moistening and drainage. To assess it, it is necessary to take into account location on the relief and characteristic of a given forest type (positive or negative landforms, upper or lower parts of a slope), as well as mechanical soil composition (loamy, sandy loam, or sandy) and its moisture, specified in the forest type description. Attention should also be paid to the site index class. With good drainage, it is usually higher (classes I-II) and with poor drainage, it is lower (classes IV-V). When a forest type is called "green moss", it is often the dry moss PFC type, and when it includes such words as "mossy", "Aulacomnium", it refers to the moist moss PFC type. In addition, it should be noted that in the moss subgroup, a PFC type does not change during a fire season. In moss cover forest types, soil and duff retain high moisture long after snow melting. Therefore, the dry moss PFC type and moist moss PFC type can be characterized for some time as the moist moss PFC type and the bog moss PFC type, respectively.

\subsection{Software Description}

We used the software package (Figure 1) developed at the Sukachev Institute of Forest to automate the process of making VF maps and maps of current fire hazard for fire behavior prediction in larch forests of the Kazakhstan Altai. The developed software can be installed on almost any personal computer running the MS Windows operating system of any version (SE, 2000, XP, Vista, 7, 8, 10).

The software package includes two components: the PGM software for calculating pyrological description of inventory plots (this software can be used as an independent product for generating fire hazard maps) and the PGM2 software for fire behavior prediction (the software uses the data calculated in the PGM software). The PGM and PGM2 software are protected by copyright state registration certificates of computer programs $[5,6]$. 


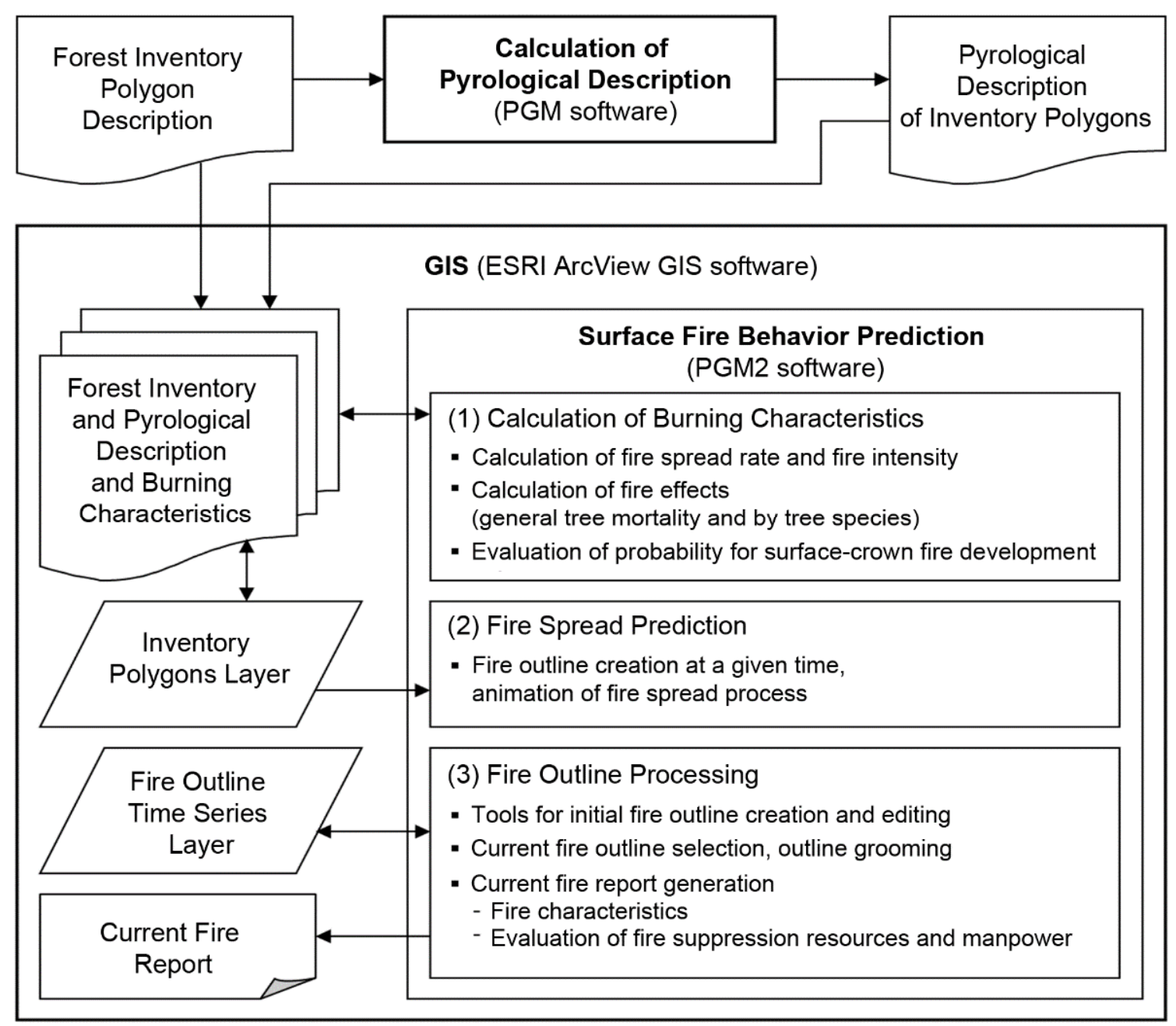

Figure 1. Structural scheme of PGM and PGM2 software operation process for calculation of pyrological description of plots (polygons) and surface fire behavior prediction.

\subsubsection{PGM Software}

The PGM software is developed in the $\mathrm{C}++$ programming language and is a tool independent of other software and can be used separately from the PGM2 software. The PGM program calculates pyrological characteristics of forest inventory plots, namely, PFC type and critical drought class (CDC), at which fire can spread over the area. The program uses a standard table containing description of inventory plots as input data. The algorithm [4] uses data on land categories, forest types, and characteristics of the first and second forest layers (species composition, age, and height). When calculating shading and CDC, characteristics of undergrowth and understory, solar exposure, and plot steepness (if any) are also taken into account. The resulting pyrological description is generated in the form of a table for three fire seasons: spring, fall, and summer. Using standard functions of common GIS applications, such as ArcGIS or MapInfo, pyrological description is linked to the cartographic layer of each inventory plot to create seasonal VF maps and maps of current fire hazard (CFH) for each specified drought class (DC). The legend of CFH maps is formed according to the principle: (1) ready-to-burn plots, if DC < CDC; (2) plots in a transitional stage, if DC $=\mathrm{CDC}$; and (3) unburnable or not-ready-to-burn plots, if $\mathrm{DC}>\mathrm{CDC}$. 


\subsubsection{PGM2 Software}

The PGM2 software was developed to automate methodology for predicting fire spread. The software uses the shell and functionality of a GIS application (ESRI ArcView GIS 3.2) as an extension module. Management of cartographic and tabular data during PGM2 software operation is carried out through the interface of ArcView GIS application and the main dialog box of the software. The algorithm for calculating current spread rate of a fire edge is based on Sofronov's empirical model [19,20]:

$$
\mathrm{Vx}=\mathrm{Vo} \times \mathrm{Kw} \times \mathrm{Kr} \times \mathrm{K} \varphi,
$$

where $\mathrm{Vx}$ is fire spread rate, $\mathrm{m} / \mathrm{min}$; Vo is basic fire spread rate, $\mathrm{m} / \mathrm{min} ; \mathrm{Kw}$ is coefficient of wind influence; $\mathrm{Kr}$ is coefficient of relative air humidity influence; and $K \varphi$ is coefficient of surface slope influence.

The PGM2 software applies a polygonal vector layer of forest inventory plots associated with tables of inventory and pyrological description (obtained in the PGM software). At the first stage, the PGM2 algorithm calculates a table of combustion characteristics for inventory plots based on a given fire danger index (Nesterov's Index), air humidity, wind direction, and wind speed. If available, data on the terrain relief (slope and exposure) are also taken into account. At the second stage of calculation, a user sets an initial ignition or ignitions (of a given shape and area) and indicates the desired duration and accuracy of fire prediction, after which calculation and animation of fire edge spread starts. As a result, a set of consecutive polygonal outlines is formed to show fire development within a specified time interval depending on the calculation accuracy. For each fire outline (burning time), at a user request, it is possible to obtain detailed information about a fire: fire area, fire perimeter, growth rates of fire area and perimeter, average intensity of a fire edge, and an estimate of resources and manpower necessary for suppression efforts, including fire barrier width, suppression rate and duration, and required number of people and/or bulldozers. In addition, probability of transition of a surface fire into a crown fire and percentage of possible tree mortality for all basic forest species are calculated for each burned plot. The software features also make it possible to arbitrarily set the location and shape of objects able to stop fire edge spread and to simulate firebreaks, rivers, or other possible fire barriers.

\section{Results and Discussion}

\subsection{Pyrological Description of Larch Forests in the Kazakhstan Altai}

Pyrological description of the Kazakhstan Altai forest types and other categories of sites (pastures, hayfields, open spaces, stone deposits) revealed predominance of litter subgroup PFC types, where identification of PFC types is more complicated. Standard forest-type descriptions usually do not provide litter characteristics; one has to draw conclusions about litter characteristics indirectly. In addition, PFC types should be identified for spring/fall and for summer separately. Litter subgroup, where a PFC layer consists of fine vegetation fuel, often undergoes considerable changes during a fire season in terms of PFC layer load, structure, and rate of drying due to differences in the rate of intake and decomposition of vegetation residues. Litter decomposes especially intensively in summer. Its PFC layer of grass residues becomes denser. Thus, one PFC type transforms into another, namely, cured grass $(\mathrm{Cg})$ in spring turns into loose litter $(\mathrm{Ll})$ in summer, and back to cured grass $(\mathrm{Cg})$ in fall. If grass cover composition is dominated by gramineous plants (e.g., Calamagrostis spp., Poa spp., Festuca spp.) and sedge (Carex spp.) (excluding evergreen sedge), then PFC type is cured grass (Cg) in spring and fall, and may transform into loose litter ( $\mathrm{Ll})$, compact litter $(\mathrm{Cl})$, or even non-conductor $(\mathrm{Nc})$ in summer, since, when the load of growing green grass (in absolutely dry mass) exceeds the load of dead vegetation residues, an almost non-flammable mixture is formed, which is conventionally called as Nc1 subtype (Table 1). 
Table 1. Description of forest types and other categories of sites in the Kazakhstan Altai according to primary fire carriers (PFC) and critical drought classes (CDC).

\begin{tabular}{|c|c|c|c|c|c|}
\hline \multirow[t]{2}{*}{ Forest Types, Categories of Sites } & \multirow[t]{2}{*}{ Code } & \multicolumn{2}{|c|}{ PFC Type } & \multicolumn{2}{|c|}{$\begin{array}{c}\text { CDC (Relative Basal Area per } \\
\text { Hectare of } 0.5-0.7 \text { ) }\end{array}$} \\
\hline & & Spring/Fall & Summer & Spring/Fall & Summer \\
\hline Subalpine larch forest & LSA & $\mathrm{Cl}$ & Nc1 & III & $\mathrm{V}$ \\
\hline $\begin{array}{l}\text { Larch forest with Vaccinium myrtillus } \\
\text { and moss cover }\end{array}$ & LChM & $\mathrm{Mm}$ & $\mathrm{Mm}$ & III & III \\
\hline Larch forest with grass cover & LT & $\mathrm{Cg}$ & Nc1 & I & $\mathrm{V}$ \\
\hline $\begin{array}{c}\text { Larch and Pinus sibirica forest with } \\
\text { moss cover }\end{array}$ & LKM & $\mathrm{Dm}$ & $\mathrm{Dm}$ & II & II \\
\hline Larch and fir forest with moss cover & LPM & $\mathrm{Mm}$ & $\mathrm{Mm}$ & III & III \\
\hline $\begin{array}{l}\text { Larch and fir forest with mixed } \\
\text { grass cover }\end{array}$ & LPR & $\mathrm{Cl}$ & $\mathrm{Cl}$ & III & III \\
\hline Larch forest with Ribes spp. Cover & LSM & $\mathrm{Cl}$ & $\mathrm{Cl}$ & III & III \\
\hline Larch forest with tall grass cover & LVT & $\mathrm{Cl}$ & Nc1 & III & $\mathrm{V}$ \\
\hline $\begin{array}{l}\text { Larch forest with gramineous and } \\
\text { mixed grasses cover }\end{array}$ & LZR & $\mathrm{Cg}$ & Nc1 & I & $\mathrm{V}$ \\
\hline Larch forest with spirea cover & LSP & $\mathrm{Cg}$ & $\mathrm{Cl}$ & I & III \\
\hline Mountain valley spruce forest & EGD & $\mathrm{Cl}$ & $\mathrm{Cl}$ & III & III \\
\hline Fir forest with shrub understory & PK & $\mathrm{Ll}$ & $\mathrm{Cl}$ & II & III \\
\hline Fir forest with grass and fern cover & PTP & $\mathrm{Ll}$ & Nc1 & II & III \\
\hline $\begin{array}{c}\text { Fir forest with grass, fern and } \\
\text { moss cover }\end{array}$ & PTPM & $\mathrm{Cl}$ & Nc1 & III & $\mathrm{V}$ \\
\hline Birch forest with grass cover & $\mathrm{BT}$ & $\mathrm{Cg}$ & Nc1 & $\mathrm{I}$ & $\mathrm{V}$ \\
\hline Aspen forest on drained soils & OSS & $\mathrm{Cl}$ & $\mathrm{Cl}$ & III & III \\
\hline Willow forest, near small stream & IVPR & $\mathrm{Ll}$ & Nc1 & II & $\mathrm{V}$ \\
\hline Pasture & - & $\mathrm{Cg}$ & Nc1 & I & $\mathrm{V}$ \\
\hline Opening (forest gap) & - & $\mathrm{Cg}$ & Nc1 & I & V \\
\hline Open forest & - & $\mathrm{Cg}$ & $\mathrm{Cl}$ & I & III \\
\hline Steep slope & - & $\mathrm{Cg}$ & Nc1 & I & V \\
\hline Stone deposits & - & $\mathrm{Cg}$ & Nc1 & I & V \\
\hline Rock exposure & - & Nc2 & Nc2 & Unburnable & Unburnable \\
\hline Stone run & - & Nc2 & Nc2 & Unburnable & Unburnable \\
\hline
\end{tabular}

Notes: PFC types: Dm-dry moss, Mm-moist moss, Cg-cured grass, Cl-compact litter. CDC-critical drought class, at which fire can spread over the area under standard environment conditions: flat surface and 0.5-0.7 relative basal area per hectare. In case of non-standard conditions, there are developed coefficients for slope and relative basal area. I-V, drought classes according to weather conditions (Nesterov's Index): I, fewer than 300 conventional units; II, 301-400; III, 1001-4000; IV, 4001-10,000; V, more than 10,000 units.

Figures 2-5 show examples of vegetation areas with different PFC types. There are no PFCs in stone runs (Figure 2). That PFC type is non-conductor (Nc2), excluding spread of flame combustion over this area. Taking this into consideration, a fire suppression crew boss can draw up an optimal fire suppression plan and effectively arrange resources and manpower for fire suppression. The territory of the Kazakhstan Altai is abundant in stone deposits, which are fire-prone in spring and dry fall, since, as a rule, they are overgrown with gramineous plants and form cured grass PFC type (Figure 3).

In summer, after regrowth of green parts of gramineous plants, fire hazard of such areas is significantly lower and fire spread is practically excluded. In spring and dry fall, larch forests with grass cover are also very fire-prone (Figure 4). In the same periods of a fire season, larch forests with tall grasses in their forest cover are less fire-prone (Figure 5) since they are most often characterized by compact litter PFC type, which becomes fire-prone under standard environment conditions only at the second drought class according to weather conditions. Larch forests of both grass and tall grass cover are not fire-prone in summer, when the load of green live mass predominates over the load of dry dead mass. The dried-up part of gramineous plants partly decomposes, and the part that remains is compacted and can only conduct flameless combustion, smoldering at a low rate. Such areas are characterized by non-conductor PFC type (Nc1) in summer. 


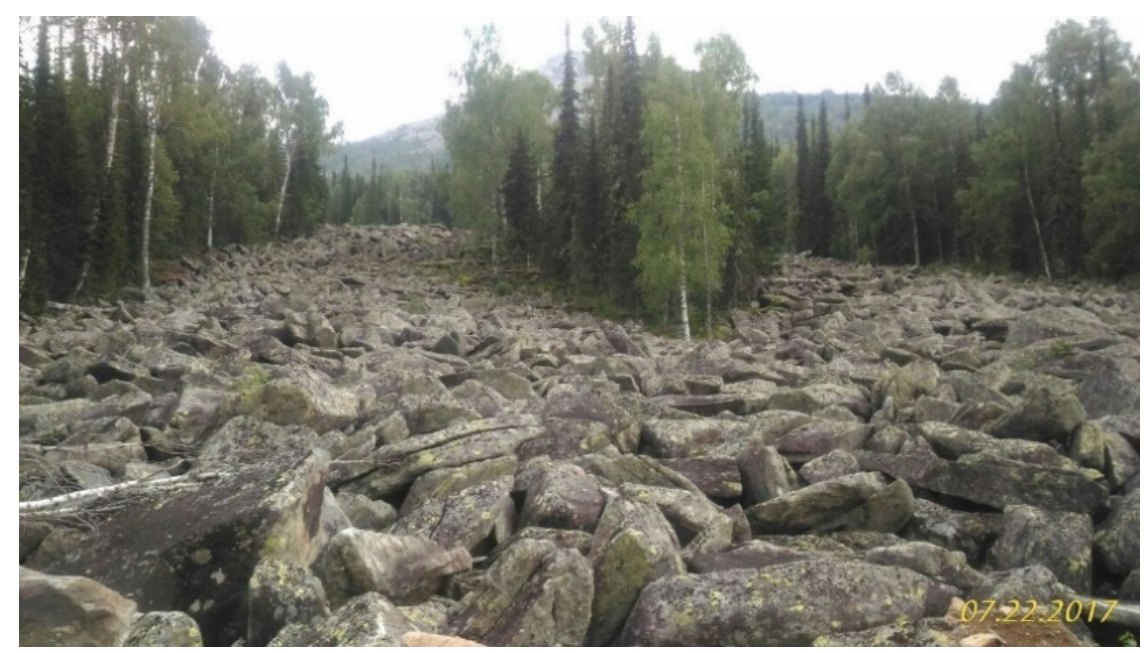

Figure 2. Stone run. Primary fire carriers are absent. Flame combustion spread is excluded.

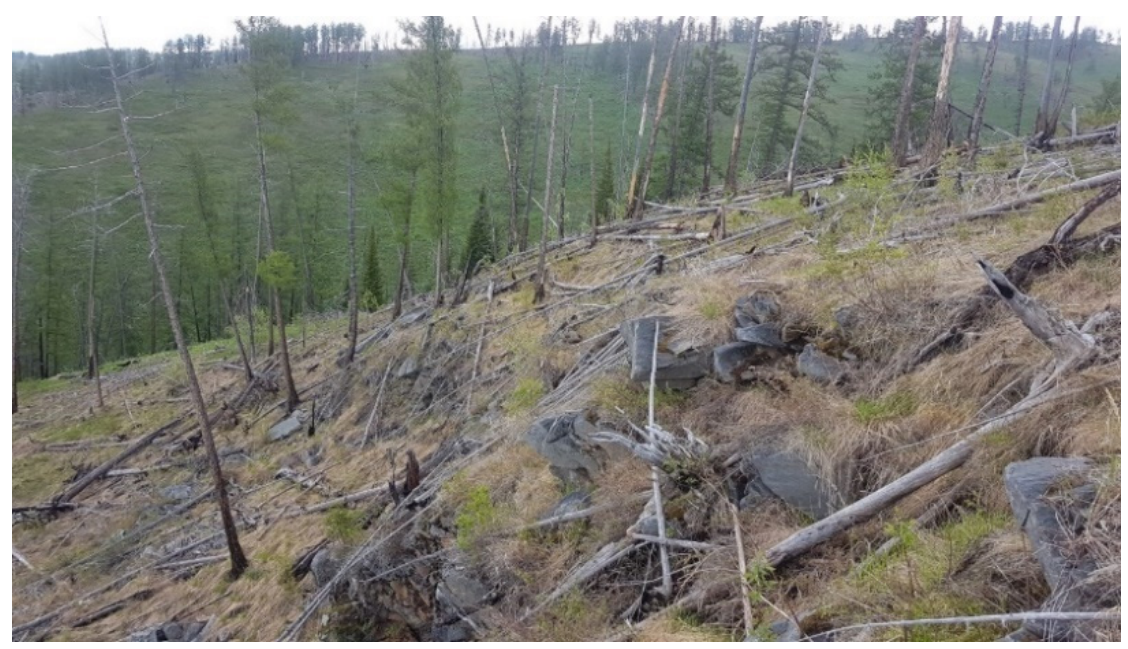

Figure 3. Stone deposits overgrown with gramineous plants. They are fire-prone in spring and dry fall under the first drought class according to weather conditions due to cured grass PFC type.

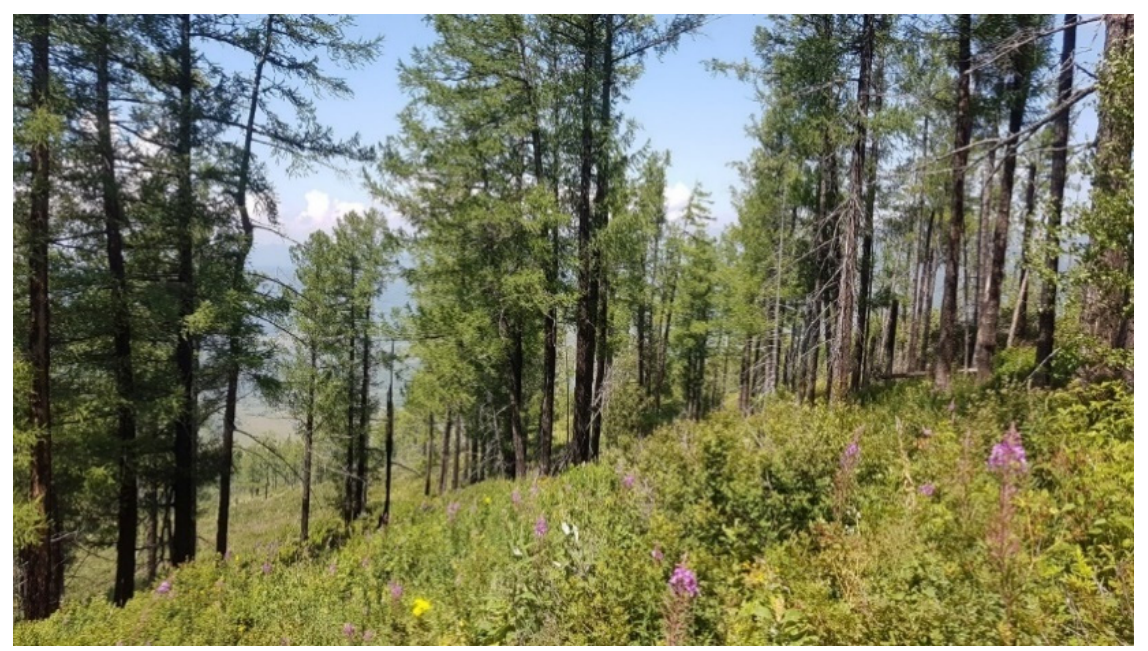

Figure 4. Larch forest with grass cover. Fire spread here is almost excluded in summer. 


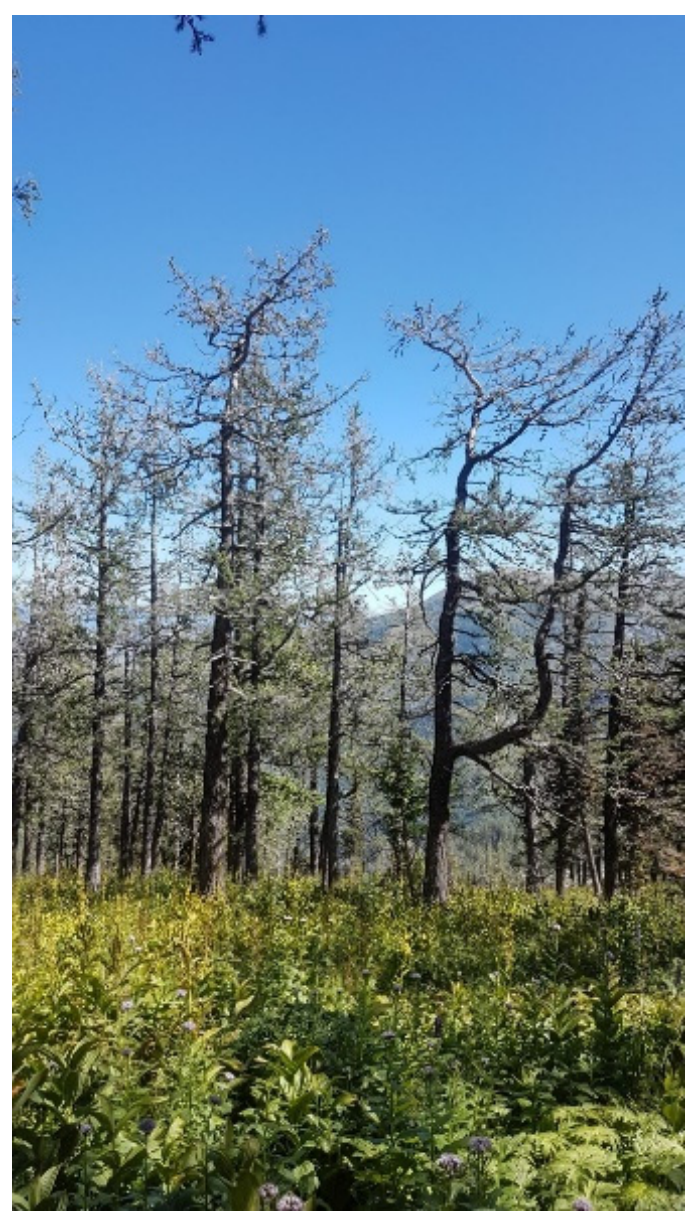

Figure 5. Larch forest with tall grass cover. Fire spread here is almost excluded in summer.

Based on the developed PGM software adapted to mountain conditions of the Kazakhstan Altai, VF maps were made. Figure 6 shows fragments of VF maps and maps of current fire hazard for different periods of a fire season. In the spring/fall period, fireprone cured grass PFC type prevails, making flame spread possible even under the first drought class; favorable factors such as mountain conditions and wind contribute to this. In summer, fire hazard of the territory is significantly lower. Under the third drought class, only some plots are at the transitional stage and most of the territory does not support fire spread. In case of severe drought (under the fifth drought class and higher), spread of flaming combustion is possible in some plots with compact litter PFC type, and flameless (smoldering) combustion is possible over most of the territory with non-conductor PFC type (Nc1), where there is dry duff under grass cover.

\subsection{Software Package for Fire Behavior Prediction in Larch Forests of the Kazakhstan Altai}

Based on the chosen fire spread model and pyrological description of larch forests and other categories of sites in the Kazakhstan Altai, our software package (PGM and PGM2) was adapted to the mountain terrain of the research area. It included automated creation of VF maps based on forest inventory data. Examples of VF maps for larch forests of the Kazakhstan Altai were made using materials available for the Markakol Forestry area. On the basis of the VF map, maps of current fire hazard were made for five drought classes. These maps make it possible to predict probability of fire spread depending on PFC state, weather conditions, and fire data for the last 10 years. Moreover, the developed software uses a VF map and calculates spread rate, fire development, and fire effects as a percentage of tree mortality in the stand and also assesses resources and manpower for 
effective fire suppression (Table 2). Figure 7 demonstrates the PGM2 software operation under a given ignition source and given weather conditions.

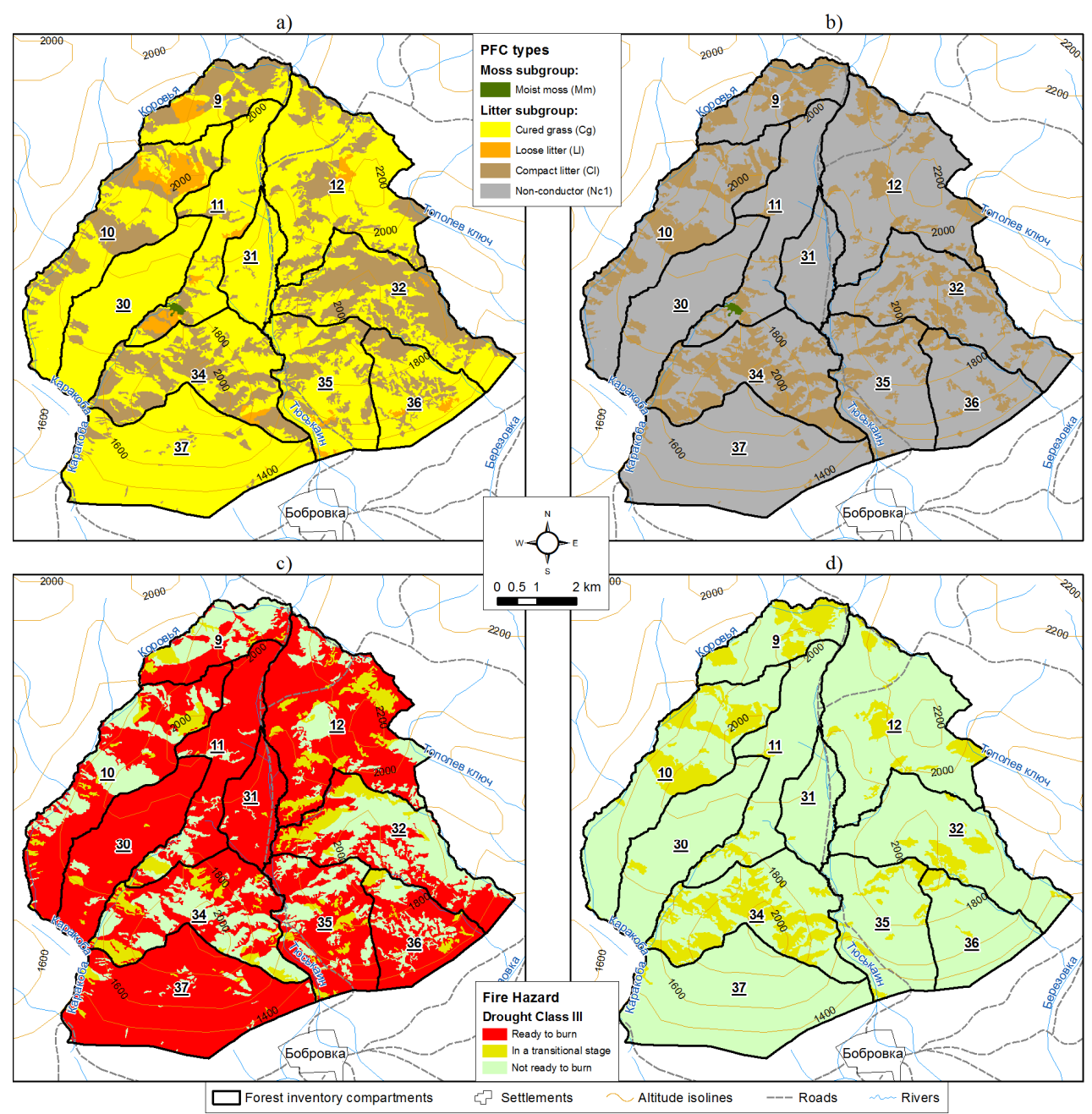

Figure 6. Fragments of VF maps for the Markakol Forestry area for periods of a fire season: (a) spring/fall; (b) summer; and maps of current fire hazard under the third drought class according to weather conditions for periods of a fire season: (c) spring/fall; (d) summer.

Table 2. Conditions and results for a simulated surface fire spread in the Markakol Forestry area of the Kazakhstan Altai (example of using the PGM2 fire simulation software).

\begin{tabular}{|c|c|c|c|c|}
\hline \multirow{2}{*}{$\begin{array}{l}\text { List of Conditions and Results for a } \\
\text { Given Vegetation Fire }\end{array}$} & \multicolumn{4}{|c|}{ Fire Development Options } \\
\hline & (a) & (b) & (c) & (d) \\
\hline \multicolumn{5}{|c|}{ Input data for fire spread model } \\
\hline $\begin{array}{l}\text { Period of the fire season: s-spring, } \\
\text { f-fall }\end{array}$ & $s(f)$ & $s(f)$ & $s(f)$ & $s(f)$ \\
\hline $\begin{array}{l}\text { Time passed after initial ignition: } \\
\text { hours: minutes: seconds }\end{array}$ & 00:00:00 & 24:15:00 & $36: 15: 00$ & 48:00:00 \\
\hline Fire danger Nesterov's index, units & 2300 & 2300 & 2300 & 2300 \\
\hline Air humidity, $\%$ & 40 & 40 & 40 & 40 \\
\hline Wind direction, degrees & 0 & 315 & 45 & 45 \\
\hline Wind speed, $\mathrm{m} / \mathrm{s}$ & 0 & 5 & 7 & 7 \\
\hline Initial ignition area, ha & 3 & 3 & 3 & 3 \\
\hline Additional ignition area, ha & - & - & 3 & 3 \\
\hline Average slope steepness, degrees & 27 & 25 & 18 & 21 \\
\hline Predominant slope exposure & SW & NW & $\mathrm{W}$ & SE \\
\hline
\end{tabular}


Table 2. Cont.

\begin{tabular}{|c|c|c|c|c|}
\hline \multirow{2}{*}{$\begin{array}{l}\text { List of Conditions and Results for a } \\
\text { Given Vegetation Fire }\end{array}$} & \multicolumn{4}{|c|}{ Fire Development Options } \\
\hline & (a) & (b) & (c) & (d) \\
\hline \multicolumn{5}{|c|}{ Fire characteristics } \\
\hline Fire area, ha & 3 & 117 & 539 & 3219 \\
\hline Fire perimeter, $\mathrm{m}$ & 669 & 4438 & 14,854 & 46,877 \\
\hline Rate of fire perimeter growth, $\mathrm{m} /$ hour & 221 & 717 & 3156 & 97 \\
\hline Rate of fire area growth, ha/hour & 2 & 23 & 210 & 186 \\
\hline $\begin{array}{c}\text { Average frontal fire spread rate, } \\
\mathrm{m} / \text { hour }\end{array}$ & 28 & 60 & 155 & 40 \\
\hline Average fire edge intensity, $\mathrm{kW} / \mathrm{m}$ & 50 & 86 & 235 & 269 \\
\hline Fire intensity assessment & low & moderate & moderate & moderate \\
\hline Optimal fire suppression rate, $\mathrm{m} /$ hour & 663 & 2150 & 9468 & 290 \\
\hline Fire barrier width, $\mathrm{m}$ & 4 & 9 & 17 & 6 \\
\hline $\begin{array}{l}\text { Use of a bulldozer for fire suppression: } \\
(+)-\text { recommended; }(-)-\text { not } \\
\text { recommended }\end{array}$ & - & + & heavy expenses & heavy expenses \\
\hline
\end{tabular}

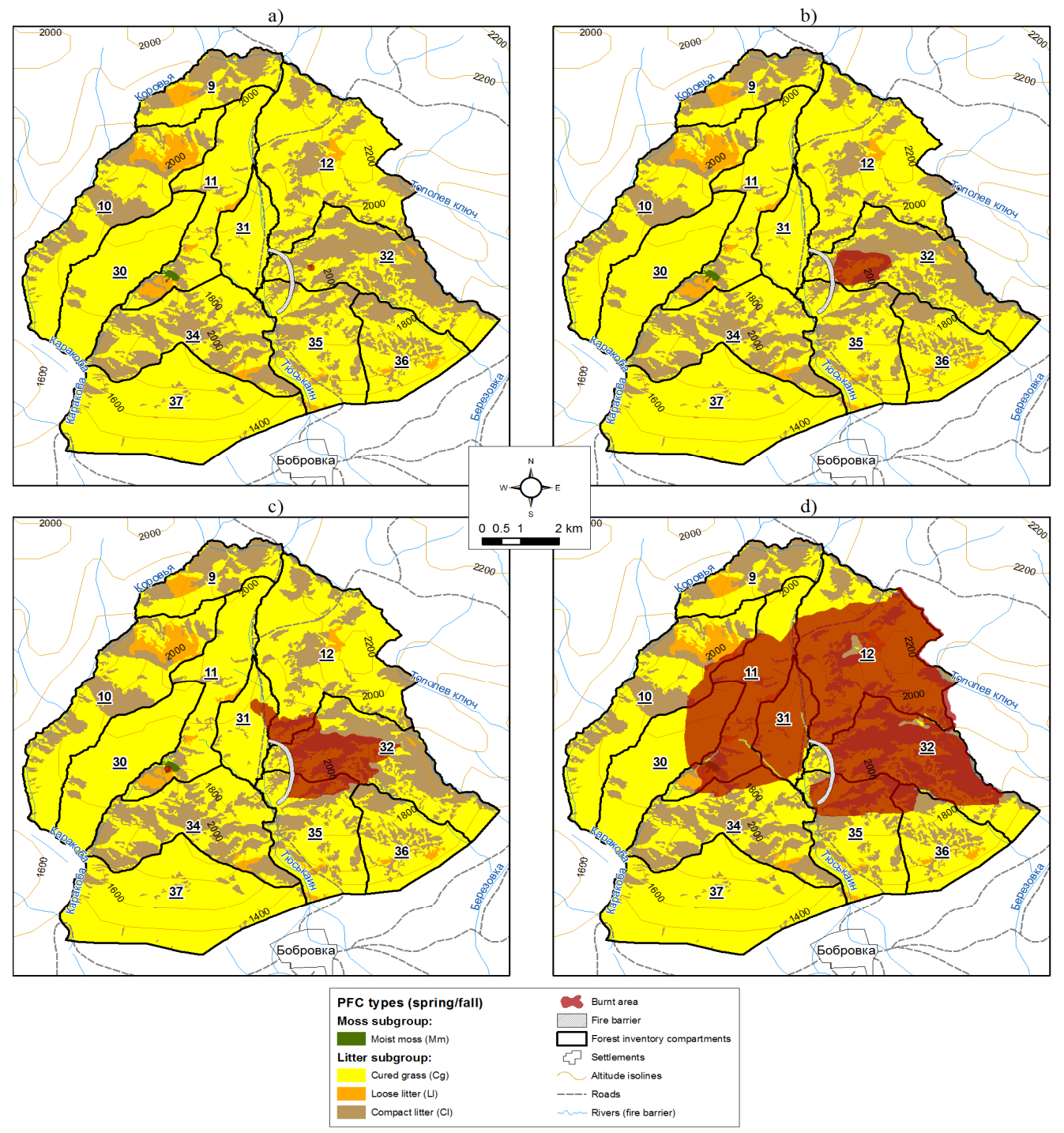

Figure 7. An example of surface fire development calculated by the PGM2 fire simulation software. Time passed after initial ignition (h:min:s): (a) 00:00:00; (b) 24:15:00; (c) 36:15:00; (d) 48:00:00. Input model parameters and calculated fire characteristics are given in Table 2. 


\section{Conclusions}

The fire behavior prediction methodology, developed at the Sukachev Institute of Forest and tested in plain conditions in Russia, was adapted to mountain conditions of larch forests in the Kazakhstan Altai. Pyrological characteristics of prevailing forest types in the region and other categories of areas were performed, including identification of PFC types, the state of which depends on weather conditions and determines possibility for flame combustion to spread over the area. This will facilitate creation of an information database for fire behavior prediction over the entire territory of the Kazakhstan Altai on the basis of available forest inventory information in GIS. Based on the PGM and PGM2 software adapted to mountain conditions, examples of vegetation fuel maps for the Markakol Forestry area for different periods of a fire season were created and propagation of a simulated fire under given weather conditions was demonstrated. Application of the obtained results in the forest fire protection of the Kazakhstan Altai will help to both reduce fire occurrence in the region and effectively use fire suppression resources and manpower.

A wider implementation of the obtained developments is possible both over the territory of Kazakhstan and Russia and over the territory of all other former Soviet republics (countries of the Commonwealth of Independent States) since forest inventory there was carried out in GIS according to a unified forest inventory scheme. The use of the proposed developments in any other country is possible only on limited territories, for example, in protected areas, using aerospace information.

Author Contributions: Conceptualization, A.V.; methodology, A.V.; software, M.K.; validation, A.V. and M.K.; formal analysis, A.K. and T.S.; investigation, M.K.; resources, A.K.; data curation, M.K.; writing—original draft preparation, A.V.; writing—review and editing, T.S.; visualization, M.K and A.K.; supervision, A.V.; project administration, A.V.; funding acquisition, A.V. and A.K. All authors have read and agreed to the published version of the manuscript.

Funding: This research was funded within the framework of the Agreement No. 10/1 (dated 25 April 2019) between the A.N. Bukeykhan Kazakh Scientific Research Institute of Forestry and Agroforestmelioration (Republic of Kazakhstan) and the V.N. Sukachev Institute of Forest SB RAS (Russia). Partial financial support was provided by the Russian Foundation for Basic Research (grant No. 18-05-00781A).

Institutional Review Board Statement: Not applicable.

Informed Consent Statement: Not applicable.

Data Availability Statement: Not applicable.

Conflicts of Interest: The authors declare no conflict of interest. The funders had no role in the design of the study; in the collection, analyses, or interpretation of data; in the writing of the manuscript; or in the decision to publish the results.

\section{References}

1. Kalachev, A.A. Forestry and Ecological Factors of Forming Dark Coniferous Stands and Principles of Rational Use of South-Western Altai Mountain Forests: Doctor (Dsc) Biology Science Thesis Summary; UGLTU: Ekaterinburg, Russia, 2016; p. 38. (In Russian)

2. Arkhipov, E.V. Fire occurrence in mountain forests of the Eastern Kazakhstan. In Intensification of Forestry in Russia: Problems and Innovative Solutions, Proceedings of the All-Russian Scientific and Practical Conference with International Participation, Krasnoyarsk, Russia, 19-23 September 2016; IL SO RAN: Krasnoyarsk, Russia, 2016; pp. 18-20, (In Russian with English abstract).

3. Kalachev, A.A.; Zalesov, S.V. Special features of post-fire regeneration of Siberian fir stands in the conditions of the south-western Altai). Lesn. Zhurnal (For. J.) 2016, 2, 47-50, (In Russian with English title and abstract).

4. Volokitina, A.V.; Sofronov, M.A.; Korets, M.A.; Sofronova, T.M.; Mikhaylova, I.A. Institut lesa im. In Forest Fires Behavior Prediction; V.N. Sukacheva: Krasnoyarsk, Russia, 2010; p. 211, (In Russian with English title, summary and contents).

5. Korets, M.A.; Volokitina, A.V. Certificate of State Registration for the Computer Program: Program for Development of Pyrological Description for Forest Inventory Plots. No. 2014660252, dated 3 October 2014. (In Russian). Available online: https://new.fips. ru/iiss / document.xhtml?faces-redirect=true\&id=313c5cf5dff01ae8d209b1fdd2a8e224 (accessed on 22 March 2021).

6. Korets, M.A.; Volokitina, A.V. Certificate of State Registration for the Computer Program: Program for Prediction of Surface Fire Spread. No. 2015661771, dated 9 November 2015. Available online: https:/ / new.fips.ru/iiss/document.xhtml?faces-redirect= true\&id=69e2f584312b479812aae78ce1fa1c81 (accessed on 15 March 2021). (In Russian). 
7. Volokitina, A.V.; Sofronova, T.M.; Korets, M.A. Vegetation fire behavior prediction in Russia. In Wood E Fire Safety, Proceedings of the 9th International Conference on Wood E Fire Safety 2020, Strbske Pleso, Slovakia, 3-6 May 2020; Springer Nature Switzerland AG: Cham, Switzerland, 2020; ISBN 978-3-030-41234-0. [CrossRef]

8. Sullivan, A.L. Wildland surface fire spread modeling, 1990-2007. 1: Physical and quasi-physical models. Int. J. Wildland Fire 2009, 18, 349-368. [CrossRef]

9. Sullivan, A.L. Wildland surface fire spread modeling, 1990-2007. 2: Empirical and quasi-empirical models. Int. J. Wildland Fire 2009, 18, 369-386. [CrossRef]

10. Sullivan, A.L. Wildland surface fire spread modeling, 1990-2007. 3: Simulation and mathematical analogue models. Int. J. Wildland Fire 2009, 18, 387-403. [CrossRef]

11. Volokitina, A.V.; Ryan, K.C.; Sofronova, T.M.; Sofronov, M.A. Selection of Fire Spread Model for Russian Fire Behavior Prediction System. In Proceedings of the VI International Conference on Forest Fire Research, Coimbra, Portugal, 15-18 November 2010; Viegas, D.X., Ed.; University of Coimbra: Coimbra, Portugal, 2010; p. 7. Available online: https://www.fs.fed.us/rm/pubs_other/rmrs_2010 _volokitina_a001.pdf (accessed on 20 March 2021).

12. Grishin, A.M. Mathematical Models of Forest Fires; TGU: Tomsk, Russia, 1981; p. 278. (In Russian)

13. Grishin, A.M. Mathematical Modelling of Forest Fires and New Ways of Fire Suppression; Nauka: Novosibirsk, Russia, 1992; p. 407. (In Russian)

14. Korovin, G.N. Technique of calculating some parameters of surface forest fires. In Collection of Scientific and Research Articles on Forestry; Trudy LenNIILKh: Leningrad, Russia, 1969; pp. 244-262. (In Russian)

15. Forestry Canada; Fire Danger Group. Development and structure of the Canadian Forest Fire Behavior Prediction System. In Science and Sustainable Development Directorate; Inf. Rep. ST-X-3; Ottawa, ON, Canada, 1992; p. 63. Available online: https:/ / www.frames.gov/documents/catalog/forestry_canada_fire_danger_group_1992.pdf (accessed on 22 March 2021).

16. Marchenko, N.A. Assessment of forest fire danger by probability of fire occurrence with a certain spread rate on the basis of landscape conditions analysis. Geogr. Prir. Resur. (Geogr. Nat. Resour.) 1993, 4, 131-136. (In Russian)

17. Podrezov, Y.V. Basic Foundations for the Method of Complex Prediction of Emergency Forest Fire Situations; VINITI: Moscow, Russia, 2001; p. 23. (In Russian)

18. Rothermel, R.C. A mathematical model for predicting fire spread in wildland fuels. In Ogden, USDA, Forest Service Research Paper; Int-115; Inter-Mountain Forest and Range Experiment Station: Ogden, UT, USA, 1972; p. 40.

19. Sofronov, M.A. Forest Fires in Southern Siberia Mountains; Nauka: Moscow, Russia, 1967; p. 152. (In Russian)

20. Sofronov, M.A. Effect of relief on forest fire in Western Sayan. In Soviet Progress in Forest Fire Control; Consultants Bureau Enterprises: New York, NY, USA, 1964; pp. 13-21.

21. Volokitina, A.V.; Sofronov, M.A. Vegetation Fuel Classification and Mapping; SO RAN: Novosibirsk, Russia, 2002; p. 314. (In Russian)

22. Volokitina, A.V.; Sofronov, M.A.; Sofronova, T.M. Topical Scientific and Practical Issues of Wildland Fire Problem. Mitig. Adapt. Strateg. Glob. Chang. 2008, 13, 661-674. Available online: https://link.springer.com/article/10.1007/s11027-007-9120-7?error= cookies_not_supported\&code=db9f18a7-f3cf-49f1-9bec-b880ed1b79d0 (accessed on 18 March 2021). [CrossRef]

23. Wright, J.C. Forest-Fire Hazard Research as Developed and Conducted at the Petawawa Forest Experimental Station; Forest Service Department of the Interior Canada: Ottawa, ON, Canada, 1967; p. 40.

24. Volokitina, A.V. Forest fuel mapping. In Fire in Ecosystems of Boreal Eurasia; Goldammer, J.H., Furyaev, V.V., Eds.; Kluwer Academic Publishers: Dordrecht, The Netherlands; Boston, UK; London, UK, 1996; pp. 239-252. Available online: https: / /link.springer.com/chapter/10.1007/978-94-015-8737-2_19 (accessed on 20 March 2021).

25. Volokitina, A.V.; Stone, T.A.; Sofronov, M.A. An Assessment of the Amount of Biomass Consumed from Wildland Fires Based on Vegetation Fuel Maps. In Proceedings of the IBFRA 2000 Conference, Edmonton, AB, Canada, 8-12 May 2000; Shaw, C.H., Apps, M.J., Eds.; Natural Resources Canada, Canadian Forest Service, Northern Forestry Centre: Edmonton, AB, Canada, 2002; pp. 249-259.

26. Kurbatsky, N.P. Technology and Tactics of Forest Fire Suppression; Goslesbumizdat: Moscow, Russia, 1962; p. 154. (In Russian)

27. Kurbatsky, N.P. Study of quantity and properties of forest fuels. In Questions of Forest Fire Science; ILiD SO AN SSSR: Krasnoyarsk, Russia, 1970; pp. 5-58. (In Russian) 